\title{
PROBLEMS AND OPPORTUNITIES OF RELOCATION
}

\author{
Martin Millspaugh*
}

I

\section{The Setring}

As the city-rebuilding movement enters its second decade of operation and growth, one often hears relocation described as "the Achilles heel of urban renewal." The words carry a warning that is clear enough: If the relocation phase is not managed successfully, urban renewal can do enough damage to families and businesses to create a wave of reaction-a reaction that might be sufficient to stop the momentum of the urban renewal process itself. There is ample justification for this view. Relocation is a difficult business at best-full of heartbreak and laced with human problems that go to the very nature of urban life. Already, serious voices are asking: Is it worth it? ${ }^{1}$ On June 27 , 1960, after a debate devoted in large part to the relocation question, the House of Representatives voted 348 to 35 to pass the Rabaut bill, ${ }^{2}$ which would stop all urban renewal in the District of Columbia until construction is completed in fifty per cent of the District's huge Southwest Redevelopment Area. ${ }^{3}$ The size of this vote, encompassing congressmen from all parts of the country, and from urban as well as rural constituencies, underlines the seriousness of the issue.

But this is only one side of the coin. In the "Achilles heel" view, relocation is regarded primarily as a responsibility -a sometimes unpleasant duty that must be discharged before we can get on with the more exciting business of rebuilding a city. This ignores the very real benefits that many families and businesses can reap from the process of relocation: the social problems that are brought to light for the first time and given expert, specialized attention; the lifting of the aspirations of families who did not know they could live in a better environment; the business opportunities uncovered by firms that are forced to give up their customary

- A.B. 1949, Princeton University. Deputy General Manager, Charles Center, Baltimore, Maryland. Former Assistant Commissioner for Program Planning and Development, Urban Renewal Administration, Housing and Home Finance Agency, 1957-60. Author, [with Gurney Breckenfeld and Miles L. Colean] The Human Side of URban Renewal (2958). Contributor to publications in the field of urban preblems.

The writer is indebted to Albert M. Copp, Program Analyst in the Urban Renewal Administration, who conducted much of the research for this paper, and to members of the Relocation Branch, Urban Renewal Administration, who gave freely of their experience and advice. The conclusions expressed, however, are the writer's own.

${ }^{2}$ For critiques of the relocation side of urban renewal, see Gans, The Human Implications of Current Redevelopmemt and Relocation Planning, 25 J. Am. Inst. of Planners I5 (1959); Robert G. Howes, Crisis Downtown: A Church Eye-VIEW of Urbas Renewal (1959).

106 CoNG. Rec. 13526-533 (daily ed. June 27, 1960).

${ }^{2}$ H.R. 8697, 86th Cong., ad Sess. (1960), passed House on June 27, 1960, referred to Senate Committee on the District of Columbia on June 28,1960 . No further action was taken. 
day-by-day habits. Any experienced relocation officer can recall such cases. Here space permits us to cite only one source. Shortly after the House action on the Rabaut bill, the Washington Housing Association made its own investigation of the relocation record in the District's Southwest Area. The WHA staff concluded:4

Relocation is never easy. When dealing with over 20,000 persons who must move, whether they want to or not, many deeply attached to their neighborhood, some dissatisfaction, disappointment and heartbreak are inevitable. Bur WHA is confident that the overwhelming number of families who accepted ... relocation assistance improved their housing considerably-some became home owners for the first time, some literally started new lives with new opportunities to enter into the main stream of community life.

Nationally, the available statistics bear out this conclusion, in superficial terms at least. The records of the Urban Renewal Administration (URA) indicate that only twenty per cent of the occupants of urban renewal areas enjoy standard housing conditions before relocation takes place, while eighty per cent are in substandard housing." After relocation, according to records compiled for 65,800 families in I43 cities, seventy-three per cent have obtained standard housing, twenty per cent have moved to quarters of which the condition is unknown, and only seven per cent are known to have relocated in substandard housing.

This record appears hopeful; certainly the momentum of urban renewal generally has not yet been slowed down by relocation difficulties. But the real impact of the relocation job is just beginning to be felt. Urban renewal, or at least the federally assisted portion of it, has only recently moved into the execution phase on a large scale. During the fiscal year ending on June 30, 1960, approximately ninety projects received federal loan and grant contracts for carrying out execution activities, compared with twenty-six in fiscal 1955. The rapid growth of project execution work is bringing the cities face-to-face, for the first time, with the magnitude of the relocation load that is generated by a full-scale local urban renewal program. There were an estimated 260,000 families to be relocated from 495 federally assisted projects that had reached or completed the final planning stage by June $30,1960^{7}$ And urban renewal, of course, is only one of many causes of the displacement of families by government action. It is estimated that the total annual displacement may be three times that caused by urban renewal alone.

Clearly, the relocation question must be candidly and creatively faced if the cities of America are going to transform themselves, through urban renewal and other community development activities, to accommodate the needs of our future urban population. The responsibility of the community and the problems involved

- Washington Housing Ass'N, No Slems in Ten Years 2 (1960).

- Urban Renewal administration, Housing and Home Finance Agency, Urban Renewal Project Characteristics 9 (1959). The classifications "standard" and "substandard" are based on definitions developed by cach locality.

- Urban Renewal Administration statistics (unpublished).

I Ibid.

- Statement of Albert M. Cole, Administrator, Housing and Home Finance Agency, in Hearings Before a Subcommistee of the Senate Committee on Banking and Currency on the Housing Act of 1958. 85th Cong., ad Sess. 73 (1958). 
in meeting that responsibility will be discussed below; but also, and possibly even more important, the question of whether relocation should be a positive program in its own right. Can relocation, in other words, cease to be merely an obstacle and take its place beside planning, redevelopment, public works, public housing, rehabilitation, and conservation-as another strong arm of the community development process?

II

\section{HistoricAL}

Slum clearance, and the construction of new housing in the place of substandard, blighted homes, got its start under the operations of the Public Works Administration, in the early 1930's. Here, as a means of expediting the land-clearance phase of the program, financial assistance was sometimes made available to the families being displaced. When the United States Housing Act of $1937^{\circ}$ transferred this program to the United States Housing Authority (predecessor of the Public Housing Administration), administrative procedures were adopted requiring local housing authorities to develop plans for the relocation of slum dwellers who were displaced from public housing sites. Between 1937 and the passage of the Housing Act of $1949,{ }^{10}$ the responsibility for relocation was recognized here and there in other clearance and rebuilding activities, both public and private. ${ }^{11}$ When World War II ended, and the backlog of construction needs created an unprecedented public building boom at a time when the nation also faced a critical housing shortage, the task of relocating families and businesses from the path of progress took on massive proportions. Most of the states and cities that established slumclearance and redevelopment programs prior to 1949 made some provision for relocation. These provisions were superseded by the requirements of the federallyassisted program that was established by Title I of the Housing Act of 1949 .

The 1949 Act made it clear that relocation was a public responsibility and an essential feature of slum clearance. The act required a local public agency carrying out a redevelopment project to have a "feasible method" for relocating displaced families; it required a showing of the rehousing resources (with a specific reference to the postwar housing shortage); and it provided for priority in public housing for families displaced from redevelopment areas, as well as from public housing sites. ${ }^{12}$ The administrative rules based on this act permitted the payment of a displacee's moving expenses and first month's rent, but only when necessary to move a family off the site; the total amount of financial assistance in each project

- 50 Stat. 888, as amended, 42 U.S.C. $\$ 1401$ (1958).

${ }^{20} 63$ Stat. 413, 414, as amended, 68 Stat. 622 (1954), 42 U.S.C. \$ I 441,1450 et seg. (1958).

${ }^{21}$ For an account of the development of various relocation activities in one city, Chicago, see Meltzer \& Orloff, Relocation of Families Displaced in Urban Redevelopment: Experiences in Chicago, in Cor EMAN Woodsury (Ed.), Urban Redevelopianst: Problems and Practices 407 (1953). The authors cite a classic case of privately-conducted relocation: the program conducted by Metropolitan Life Insurance Com. pany at a cost of $\$ 200,000$, to move 3,000 families from the site of the Stuyvesant Town development in New York City in 1944.

${ }_{10} 70$ Stat. 1097, 42 U.S.C. $\$ 1455$ (c) (1958). 
had to be less than the estimated combined cost of the delays and eviction proceedings that would result from familics refusing to move. ${ }^{13}$ This rationale called for financial assistance as an incidental cost of redevelopment, rather than for the benefit of the displacee.

The next significant federal law from the point of view of relocation was the Housing Act of $1954,{ }^{14}$ which converted slum clearance and redevelopment to "urban renewal," and made possible the creation of the URA as a full-fledged constituent of the Housing and Home Finance Agency (HHFA). The emphasis was shifted from individual redevelopment projects to the concept of "an effective program ... for attacking the entire problem of urban decay."15 With respect to relocation, this involved: (I) the rehabilitation of structures wherever they could be salvaged (replacing the total clearance concept and thus easing the potential relocation pressures); and (2) the requirement that a city adopt a "workable program ... for effectively dealing with the problem of urban slums and blight within the community," ${ }^{16}$ which has been interpreted by HHFA to include a rehousing program for displaced families. ${ }^{17}$ The 1954 Act also established the approval of a local public agency's relocation plan as a nondelegable function of the Housing Administrator.

Two years later, in the Housing Act of $1956,{ }^{18}$ it was determined for the first time that displacees could receive financial assistance as a matter of right, rather than as a means of expediting the slum-clearance process. Local public agencies were authorized (though not required) to make payments to all dislocated families, individuals, and businesses for "reasonable and necessary moving expenses and any actual direct losses of property," up to a maximum of $\$$ roo per family or individual, and $\$ 2,000$ per business establishment. There were doubts whether state laws and constitutional provisions would permit local public agencies to extend compensation in excess of an acquisition award; so the 1956 Act provided for the relocation payments to be absorbed by a 100 per cent federal grant. In 1957 , the payment limit for businesses was increased to $\$ 2,500$, and the law was amended to allow HHFA to permit a local public agency to make fixed payments in lieu of actual moving expenses to all eligible families and individuals. ${ }^{19}$ In the Housing Act of 1959, both family and business limits were increased, to $\$ 200$ and $\$ 3,000$, respectively, and the coverage of relocation payments was expanded to include those who move from properties acquired in an urban renewal project by any governmental action, or code enforcement, or rehabilitation connected with the project. ${ }^{20}$

13 Urgan Renewal administration, Housing and Home finance Ageñcy, Manual of poljcies and Requirements for Local Public Agencies, pt. 2, ch. 6, 54 (May 16, 1951, superseded).

16 68 Stat. 590, x2 U.S.C. $\$ 1703$ (1958).

${ }^{15}$ President's Advisory Comis. on Government Housing Policies and Programs, Report I (i953).

${ }^{10} 63$ Stat. 414 (1949), 68 Stat. 623 (1954), 42 U.S.C. S 145I(c) (1958).

${ }^{17}$ Housing and Home Finance Agency, How Localities Can Develop a Workable Program ron CoMMUNity IMPROVEMENT 44-46 (1960).

${ }^{18} 63$ Stat. 417 , as amended, 70 Stat. I100, 42 U.S.C. 5 1456(f) (1958).

10 63 Stat. 4I7, as amended, 71 Stat. 300, 42 U.S.C. $1456(f)$ (1958).

${ }^{20} 63$ Stat. 417, as amended, 73 Stat. 674, 42 U.S.C.A. 5 1456(f) (Supp. 1959). 
The Housing Act of 1959 contained another section of great significance for relocation. It provided for a new program of grants to assist localities in the preparation of "community renewal programs," designed to appraise a locality's total need for all types of renewal measures and its total resources for putting those measures into effect. ${ }^{21}$ With this information, a community can determine the maximum rate at which urban renewal can be carried out in relation to local conditions, and proceed to schedule its operations-both federally assisted and nonassisted-in order to eliminate blight in all its forms. In proposing this legislation, HHFA spokesmen made it clear that the extent of relocation resources was one of the principal factors governing the rate at which a community could move ahead with urban renewal, and that it is important to measure such limitations on a community-wide basis before an all-out program for the elimination and prevention of slums and blight is attempted. ${ }^{22}$

As the federal urban renewal statute now stands, it is also important to note a dual emphasis in the relocation provisions: first, on rehousing and relocation requirements (the local public agency must have a satisfactory relocation plan and furnish evidence of adequate rehousing resources); and, second, on relocation payments. The requirements, covered by section $105(\mathrm{c})$ of the act, ${ }^{22 x}$ apply only to families, while the payments, covered by section $106(f),{ }^{22 b}$ may be made to families, individuals, and businesses. The URA encourages local public agencies to provide the same relocation and referral services for individuals and businesses as they do for families, but it is not obligatory.

It is curious that in tẹn years of activity under Title I of the Housing Act of 1949 , as amended, there has not been a great deal of litigation in the field of relocation. Of the few cases that can be cited, ${ }^{23}$ none has so far had a profound effect on the law or administrative requirements governing relocation activities. The major battles of litigation, if there are to be such, lie in the future. In fact, the time may be passing when the law of relocation will stand or fall on the urban renewal provisions in Title I. Since 1949, there has been a growing awareness of the relocation problems caused by the acquisition of property for other public purposes. Twice, in 1955 and 1958, the National Association of Housing and Redevelopment Officials has adopted resolutions urging that relocation assistance be provided in other federal,

${ }^{11} 63$ Stat. 380 , as amended, 73 Stat. 672, 42 U.S.C.A. 5 1453(d) (Supp. 1959).

2s Statement of Richard L. Steiner, Commissioner, Urban Renewal Administration, in Hearings Before a Subcommittee of the Senate Committee on Banking and Currency on the Housing Act of 1958, 85th Cong., 2d Sess. 125-26 (1958).

=22 63 Stat. 416, as amended, 70 Stat. 1097, 42 U.S.C. 1455 (c) (1958).

${ }^{25 b} 63$ Stat. 417 , as amended, 71 Stat. 300,42 U.S.C. $51456(f)$ (1958).

${ }^{23}$ Hunter v. City of New York, 121 N.Y.S.2d 841 (Sup. Ct. 1953); McAuliffe \& Burke Co. v. Boston Housing Authority, 334 Mass. 28, 133 N.E.zd 493 (1956); Gart v. Cole, 166 F. Supp. 129 (S.D.N.Y. 1958), affd, 263 F.2d, 244 (2d Cir. 1959), cert. denied, 359 U.S. 978 (1959); Tate v. City of Eufaula, I65 F. Supp. 303 (M.D. Ala. 1958); Barnes v. City of Gadsden, 174 F. Supp. 64 (N.D. Ala. 1958), aff', 268 F.2d 593 (5th Cir. 1959), cert. denied, 36r U.S. 915 (1959); Housing and Redevelopment Authority of the City of Minneapolis v. Minneapolis Metropolitan Co., 104 N.W.2d 864 (Minn. 1960). 
state and local programs. ${ }^{24}$ The principle has been slow to catch on, however. In 1951 and 1952, relocation payments were provided for occupants of properties acquired by the Department of Defense, and similar legislation was enacted in 1958 for the water conservation and devclopment projects of the Bureau of Reclamation, Department of the Interior. ${ }^{25}$ In 1959 , the General Services Administration requested Congress to authorize relocation payments for projects involving land acquisition by any agency of the executive branch. ${ }^{26}$

It has been suggested by a number of sources that the federal-state highway program should make some provision for relocation assistance, but no national legislation has yet been adopted. On the future of relocation payments generally, however, a straw in the wind may be furnished by the law passed by the Maryland legislature in 1959, which requires the payment of moving costs to those who are displaced by any form of public acquisition, whether by the state itself (as in the case of the highway program) or by local action. ${ }^{27}$

\section{III}

\section{Problems}

\section{A. Housing Resources}

Had the safeguards for displaced families not been included in section 105 (c) of the Housing Act of 1949, there is some doubt that the act could have mustered enough votes for passage. These basic ground rules-the relocation requirements of 1949-have remained virtually unchanged to this day. Before obtaining a federal loan or grant to carry out a project, a local public agency must show:

r. that it has a feasible method for relocating the families living in properties to be acquired; and

2. that standard housing units will be available to the displaced families

a. at rents or prices they can afford,

b. in areas "not less desirable" than the project area with respect to utilities and facilities, and

c. in locations accessible to the relocatees' places of employment.

Obviously, there are only two sources of relocation housing: public housing, in the form of either ncw units or vacancies, and the private housing supply.

\section{Low-rent public housing}

From surveys of the income reported by families displaced by urban renewal, it appears that slightly more than fifty per cent would be eligible for low-rent public

"Nat'z Ass'N of Housing and Redevelopment Officials, Recommendations on Relocation Policy I-3 (1960).

${ }^{28} 72$ Stat. 152, 43 U.S.C. F 1231 (1958).

"n S. 2583 , 86th Cong., 2d Sess. (1960), passed by the Senate, June 3, 1960; referred to the House Committee on Government Operations on June 6, 1960 . No further action was taken.

${ }^{17}$ Md. Laws 1959, ch. 688. 
housing. ${ }^{28}$ This figure, or one close to it, is often cited as a measure of the need for public housing that is created by urban renewal. It is unsettling to discover, therefore, that of the families relocated in the past, less than twenty per cent have actually moved into public housing. ${ }^{29}$ Several local studies show an even greater discrepancy; in the first two years of operation of Philadelphia's central relocation office, eighty per cent of the dislocated families were found to be eligible for public housing, sixty-seven per cent were referred to public housing, but less than fifteen per cent moved in. ${ }^{30}$ In a survey of families to be relocated from New York's West Side Renewal project, it was found that sixty-eight per cent were apparently eligible, but only sixteen per cent said they wanted to live in public housing. ${ }^{31}$

It should be pointed out that some of the families who are within the income limits for public housing are disqualified for other reasons: they may be considered undesirable (families have been barred from public housing because of police records, alcoholism, illegitimacy, rent delinquency, gambling, disorderly conduct, mental or physical illness, social disease, or juvenile delinquency) $;^{32}$ or the family income may be too low (a public housing project must have enough income to pay operating costs, and hence it is sometimes necessary to maintain a distribution of incomes which shrinks the number of units available to very-low-income families); or a family may be too large for the available public housing units (many local housing authorities, like the population experts, failed to foresee the national growth in number of children per family, and until recently, the Public Housing Administration's cost limit of $\$ 17,000$ per unit militated against the construction of large units).

But even when these mechanical causes have been accounted for, there is evidence of a rejection of public housing by many of those who, theoretically, are most in need of it. Several investigators have attempted to identify the reasons for this. ${ }^{33}$ Their findings can be grouped under four headings: ( $I$ ) the desire to stay close to the old neighborhood, whether public housing is available there or not; (2) the feeling that a stigma attaches to residents of public housing; (3) an unwillingness to accept the rules and regulations that go with publicly administered housing (among other things, slum families often wish to spend a smaller proportion of family income on housing than is required in public housing); and (4) dislike of the physical character of public housing projects (relocatecs mentioned distaste for elevator living, for concrete floors, and so on).

Clearly, the relocation plan for an urban renewal project will break down in operation if the standard rehousing resources for low-income families are calculated

${ }^{2 s}$ Urban Renewal Administration statistics (unpublished). The figure was actually $52 \%$ as of June 30, 1959.

${ }^{20} \mathrm{lbid}$. The figure was $18 \%$ as of June $30,1959$.

30 Philadezpha Hodsing Ass's, Rezocation in.Pyilá̉eliphia 29 (1958).

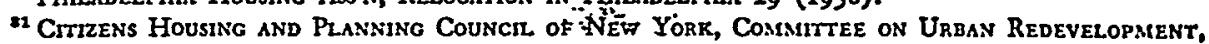
Toward a Better New York: A Report on the Urban Renewal Problems of the City, with RecomMENDATIONS I4-15 (1960).

32 Cf. Philadelphil Housing Ass'N, op. cit. silpra note 30, at 22-23.

2ะ Id. at 30; Gans, supra note 1 , at 28 . 
solely from the number of available public housing units, while more than half of the low-income families relocate elsewhere. The "elsewhere" in this case may mean substandard housing, or housing beyond their means. Solutions for this problem are not easy to find, but it has important implications for those who are responsible for the administration of urban renewal programs. This has not gone unrecognized, and already public housing is being reexamined from many perspectives. The avenues that appear most promising from the relocation point of view are: (I) possible revision of the formula governing project income versus operating costs; (2) provision of social work resources in a manner that would permit admission of more of the "problem families" (perhaps an answer lies in the creation of "staging areas," where undesirable families can be rehabilitated before assignment to a regular project); (3) a crash program for the construction of large-family units-perhaps through the purchase and rehabilitation of existing homes; (4) exploration of the possibilities of relocating groups of families, who are related by kinship or ethnic ties and wish to remain together, in blocks of public housing units; (5) experimentation with new forms of public housing-forms that would eliminate the stigma from public housing projects, the institutional character of the physical structures, and possibly some of the need for managerial red tape. A list of the new directions that have been suggested or tried in this field would run partially as follows:

a. rehabilitation of single-family homes in existing neighborhoods for public housing use;

b. construction of single-family homes in public housing projects;

c. construction of "vest pocket" projects on sites scattered through existing neighborhoods;

d. arrangements to permit public housing tenants to start buying their homes when their incomes exceed the limits for continued occupancy.

In addition to these suggestions for reorientation of the public housing program, several communities have experimented with other forms of subsidies for low-income displacees. Most common is the practice of making city funds available to pay the difference between the rent a relocatee can afford to pay and the rent in his new quarters. ${ }^{34}$ However, in some localities, foundations and other philanthropic groups supply these funds. ${ }^{38}$

Finally, Dr. Ernest M. Fisher, of Columbia University, has suggested a broadscale reorganization of the urban renewal and public housing programs, so that the housing needs and the housing resources created by community development activities could be merged into one context, with a single administrative focus and a single contract with the federal government. ${ }^{36}$ Dr. Fisher's detailed recommendations deserve careful study; space permits mention here of only two, which appear to be possible of statutory and administrative implementation: ( $I$ ) the creation of a Wis.

"Examples of cities employing this practice are Battle Creek and Port Huron, Mich., and Madison,

${ }^{28}$ East Chieago, Ind., Fargo, N.D., and Topeka, Kan., among others, may be cited as illustrations here.

20 Ernest M. Fisher, A Study of Housing Programs and Policies (1960). 
"graded inventory" of public housing units, ranging from minimum quality rental units to new subdivision housing purchased from private home builders; and (2) the provision of public housing loans for indigent slum home owners, to enable them to rehabilitate their homes, instead of being forced to relocate and thus join the public housing caseload.

\section{Private housing}

Thus far, we have discussed only the rehousing resources for the fifty per cent of displaced families who are eligible, in terms of income, for public housing. The remaining fifty per cent present an even more complex picture. Presumably, a great many fall into the categories that have been the subject of more recent controversy and debate than any other facet of urban life: the "middle-income" or "lower"middle-income" family. Definitions of these categories are as numerous as proposals for middle-income housing solutions. Until recently, a convenient definition of the "lower-middle-income" group was provided by the statutory twenty per cent gap between the incomes of families served by the private housing market and the incomes of families who could be served by public housing. The Housing Act of 1959, however, provided that for families dislocated by governmental action, the gap may be reduced to five per cent, or, in effect, eliminated. ${ }^{37}$

There will be no attempt made here to suggest ways of solving the middleincome housing riddle. The supply of housing at almost any level of income is a matter of concern for families within that level, whether they are dislocated or not. Obviously, no massive community development program is likely to succeed if adequate housing is not available at the proper price and in the proper location for the families who will be shifted about by governmental and private development actions. There are two aspects of the housing supply picture, however, which are directly related to the urban renewal program.

First, it is now clear that, in the short run at least, slum clearance tends to reduce the quantity of housing available to the families who lived in the slum. In most cases, the new housing which is being built on cleared sites in urban renewal projects is high-rise, high-cost, and therefore relatively high-rent housing. Unless existing statutes or practices are changed, displacees will seldom be housed in the area where they lived before. This was one reason for the widespread acceptance of the rehabilitation emphasis in the Housing Act of 1954: the relocation load will be reduced if clearance affects only those structures that cannot be rehabilitated. But experience is showing that rehabilitation, too, causes displacement, although usually less than is caused by clearance. This happens in two ways: through code enforcement, which eliminates overcrowding and dislocates the excess occupants, and through the increased rents that may be required to finance necessary improvements to the structure.

Second, while all families may be faced with the housing supply question, the problem that is peculiar to displaced families is timing; displacees have little or no control

\footnotetext{
" 50 Stat. 895 (1937), as amended, 73 Stat. 680 (1959), 42 U.S.C.A. 5 1415(7)(b) (Supp. 1959).
} 
over the fact that they must find a new dwelling unit, regardless of the housing supply and demand picture at the time. Furthermore, they must compete with others who also have no control over the timing of their appearance in the housing market. This includes the displaced families who are eligible for public housing but do not choose to accept it, new migrants moving into the city, new families created by population growth, and families who are displaced by other government and private development programs. As pointed out above, other public programs may displace twice as many families as urban renewal; ${ }^{33}$ this ratio will undoubtedly increase, as the Interstate Highway program is completed in the rural spaces between cities and begins carving swathes through densely-populated urban areas.

Because families displaced by urban renewal have limited control over the decision to move, in a market where competition from other displaced persons is rising, the success of a relocation plan depends on: ( 1 ) the success with which vacancies can be located in standard existing housing, and (2) the provision of new units on the market at the right time and the right price. These two factors will be considered separately.

With respect to the location of suitable vacancies, a body of relocation expertise is growing up as the urban renewal program moves more widely into the execution phase. Normally, a relocation plan will call for the discovery and listing of suitable existing vacancies in the community, by size and by price; the inspection of vacant units to establish that they are decent, safe, and sanitary; and a procedure for referring dislocatees to a series of standard housing vacancies until a satisfactory rehousing solution is found. Localities are required by URA to provide for inspection of the dwelling units occupied by self-relocated families, as well as those relocated by the local public agency. It is important, obviously, that the relocation staff have access to qualified real estate advice, and that liaison be established with the local welfare department, which furnishes much of the rent money for the lowest-income families. There should also, if possible, be some method for identifying, and black-listing, slum landlords whose properties are known to be overpriced and poorly maintained.

In addition to these normal techniques, relocation administrators can vastly improve the success of their operations by imaginative use of possible sources of available housing. In Philadelphia, the central relocation agency discovered that foreclosure sales under GI mortgages produced forty to fifty houses a month-of which many were priced less than $\$ 10,0000^{39}$ Municipal sales of tax-delinquent properties may provide another source. In many cities, the relocation staffs persuade local utility companies to supply a daily list of work orders for the discontinuance of service from houses and apartments. In New York City and several other cities, "finder's fees" are paid to real estate brokers who produce vacancies that can be used for relocation purposes. $\$ 0$

s* See note 8 supra.

"Petzadelphin Housing Ass's, op. cit. supra note 30, at 38.

${ }^{20}$ Anthony J. Panuch, Rezocation in New York City 37 (1959). 
It has been suggested at times that the granting of federal urban renewal assistance should be made contingent upon certain additional relocation practices (ie., make relocation payments only to families who move to standard housing; require redevelopers to build new relocation housing as part of the disposition agreement; adjust the amount of the federal capital grant according to the rent level of new housing to be built in the cleared area). Such methods do not appear desirable, because of possible interference with the free choice of the relocatees, or with the normal operation of community planning and the market for land. There can be little argument, however, with the suggestion that local public agencies should provide expert advice to relocatees who want to find their own housing or that the agencies should take some responsibility for seeing that new or rehabilitated housing is provided to meet the needs of dislocated families.

One of the Federal Housing Administration's (FHA) programs of mortgage insurance, created in 1954 under section 221 of the National Housing Act, ${ }^{41}$ is designed expressly for the purpose of providing new and rehabilitated housing, at especially liberal terms, for families displaced by urban renewal and other government action. Since then, the "221 program" has not compiled an impressive record. Late in 1959, an exhaustive study compiled under the supervision of Albert Thompson, Special Assistant to the Housing Administrator, pointed up some disturbing facts, which are exemplified by the following figures: ${ }^{2}$

-although by the end of 1959 the HHFA had certified 299 localities as being eligible for a total of 105,448 units of section 22r housing, applications had been received for only 32,261 units, and only 18,371 had reached the start of construction;

-out of the 32,261 units covered by applications for section 221 mortgage insurance, only fourteen per cent involved the rehabilitation of existing housing;

-only thirty-two per cent of the new section 22r units constructed were actually occupied by displaced families (if no displacee appears to acquire a section 221 unit in sixty days after it is offered for sale, it may be sold on the open market);

-although section 221 has permitted the construction of rental units by nonprofit organizations since 1954, only eighteen per cent of the units applied for were rental units; ${ }^{43}$

-more than ninety per cent of the section 22I mortgages insured by FHA were being presented for purchase by the Federal National Mortgage Association (FNMA), rather than being retained by private investors.

¿68 Stat. 599, I2 U.S.C. \$ I7x5l (1958).

"Albert Thompson, An Evaluation of the Section 221 Relocation Housing Program (1959). The statistics in this paragraph follow the organization of the Thompson report, but have been revised from the statistics given as of October 31, 1959, to those of December 31, 1959.

4S Section 221 of the National Housing Act, as amended by $\$$ r10(c) of the Housing Act of 1959 , authorized the construction of rental housing for profit, under certain conditions, although through July 1960, the FHA had reccived no applications. 
What were the reasons for this unsatisfactory performance? The conclusions of the Thompson report can be summarized only briefly here. In general, the problems cited as working against success are the following:

I. a lack of understanding of section 221 by local officials and the local homebuilding and real estate industries (creating a lack of accurate information and advice for builders and potential buyers);

2. the difficulty of constructing new housing in some communities within the section 221 mortgage ceilings of $\$ 9,000$ and (for high cost areas) \$12,000;

3. the difficulty of finding sites for low-cost housing, particularly where there are rigid patterns of racial segregation;

4. sales prices which exeed the buying capacity of the displaced families;

5. the low credit standing of many displaced families, coupled with displacees' resistance to FHA processing delays and credit investigations;

6. lack of appeal, from the point of view of location and design, of some of the section 22 I housing actually constructed;

7. the lack of a demonstrated technique for profitable rehabilitation of housing on a mass scale; ${ }^{41}$ and

8. the difficulty of timing the production of new housing to coincide with the relocation of eligible families (both events depend on a multitude of variables, and are extremely difficult to predict).

In spite of the problems and the unsatisfactory record to date, however. the Thompson report found that not all the performance had been bad; and as a whole, the record improved after the terms of section 221 were liberalized by Congress in 1956. The larger cities had the worst record, it was found, but, on the other hand: ${ }^{48}$

Section 221 accomplishment has been striking in some communities. It has provided excellent new construction and substantially improved housing avallable to low income displacees and especially to minorities.

Where section 22x housing has been a success, it has not only provided for an increase in home ownership, but also given the protection of a mortgage contract to low-income families who might otherwise have been forced to resort to installment purchase contracts, with all the accompanying pitfalls and possibilities for exploitation of an unwary or uninformed buyer. Since many displacees are ignorant of the techniques and legalities involved in a real estate transaction, this facet of section 221 has an importance that should not be overlooked.

In short, the record indicates that section 221 may have potentialities far beyond what has been demonstrated to date. The Thompson report points out the conditions that were present in most of the successful cases: community understanding and support for the program, the availability of low cost sites, and the ability to construct new housing within the statutory mortgage limits. Where these conditions

"Although isolated entrepreneurs have been successful in rehabilitating existing housing with $\mathbf{S} 22 \mathrm{r}$, there has been little evidence of large-seale duplication of their techniques.

"Thompson, op. cit, supra note 42, at i4. 
were met, it has been possible to construct section $22 \mathrm{I}$ housing successfully, though this did not guarantee that the units would ultimately be occupied by dislocated families. In order to achieve a high ratio of success in this direction, it was found necessary to offer the units on the market at the right time; to canvass potential relocatee buyers so that their desires were met with respect to location, design, and price; and to merchandise the new units aggressively among dislocated families.

Through all of these findings, the single theme that stands out is the need for community understanding and support of a relocation housing progranz. If local public agency officials do not encourage and support the construction of new section 22 r housing as an objective of the community, and provide both builders and buyers with the necessary information, assistance, and advice, private industry can hardly be expected to undertake the difficulties and risks of pioneering a complex new program. If real estate, home-building, and financial interests, on the other hand, do not assume some of that burden as a service to the community, no amount of official sympathy will get the housing built. But if both the community, through its local government officials, and the businessmen organize a creative, ${ }^{48}$ aggressive approach to the problem, there is every indication that section 22r has a potential that is far from exhausted.

\section{B. Moving Costs}

The most universal problem that confronts the families displaced by urban renewal, or other government actions, is simply the cost of moving a home and all its accoutrements. As mentioned earlier, the federal law authorizes a local urban renewal agency to reimburse displacees for out-of-pocket losses attributable to "reasonable and necessary moving expenses and any actual direct losses of property," up to a limit of $\$ 200$ for a family or individual ${ }^{47}$ and $\$ 3,000$ for a business. The cost is charged to a roo per cent federal grant, which is added to the normal capital grant made to the local agency to help meet net project costs.

Experience has shown that in the case of families and individuals, the "losses of property" clause is either superfluous or unworkable; ninety-nine per cent of the total paid by the federal government has gone to cover moving costs. Furthermore, the $\$ 200$ limit on payments for moving costs appears to be more than adequate in the great majority of cases; of the first 16,500 payments made to families, the average payment was $\$ 65: 22 .{ }^{48}$ Slum families are not, of course, overly encumbered with possessions. There may, however, be other costs involved in relocating a family, such as utility deposits, appliance installations, and payment of first month's rent in advance; or, if a home is purchased, down payments, closing costs, necessary altera-

"Examples of the creative approach have been provided by a southern mayor, who annexed land for section 221 housing when no suitable site within the city could be found, and by the formation in screral northern cities of groups of financial institutions which accept section 221 mortgages on a pool basis, each one accepting a portion of the risk as a civic duty.

"7 Under a recent ruling of the Internal Revenue Service, such payments are not taxable as personal income. In the case of a business, the payment is offset by the actual expense, and thus eliminated from tarable income. Sec Rev. Rul. 60-279, I960 INr. Rev. Bull. No. 35, p. 8.

'B Urban Renewal Administration statistics (unpublished). 
tions, and decorating expenses. In addition, some familics may suffer hidden or indirect costs, such as the loss of support from family members living nearby or the surrender of income-producing property that cannot be replaced.

No one has yet devised a simple means of providing for all the various losses that might be sustained by a displaced family, though attempts have been made to solve parts of the problem. In New York City, relocatees are paid bonuses in addition to the payment of moving expenses if they relocate themselves without the help of public authorities. ${ }^{49}$ The Port of New York Authority has also made payments for decoration of the new dwelling unit, at a flat rate of $\$ 3^{\circ}$ per room, up to a maximum payment of $\$ 210.00$ In the bill submitted to Congress by the General Services Administration last year, ${ }^{31}$ authorization would be given to federal agencies to pay for closing costs on a new home and for time lost from employment during the move, in addition to moving expenses and losses of property. No one has successfully argued, however, that the Government should pay what are potentially the most expensive types of relocation costs-the difference between the acquisition award for an old property and the price of a new one, or the cost of major improvements at the new location. The most promising answers for these items appear to lie in the direction of improved acquisition appraisal techniques, ${ }^{52}$ and perhaps a reduction (or moratorium) of rents during the period after acquisition and prior to the move, when a family's former home is owned by the local public agency.

With increasing frequency in recent months, questions have been raised about whether the present federally financed relocation payments are adequate, in the face of the actual cost of moving a home or business. Most often, however, the question is raised with respect to the dollar limits on the payments, rather than the type of costs that are eligible for reimbursement. Numerous bills introduced in the Eightysixth Congress would have provided for increases in the limits on federal payments or removed the limits altogether. The HHFA agreed that the existing limits result in some hardship (principally among some types of businesses), but the agency argued that the problem is not one to be solved by federal funds alone. As a result, the Administration suggested legislation that would permit higher limits wherever localities are willing (and permitted by state law) to include relocation payments in gross project costs-and, therefore, to share this expense in the same manner as the localities share in other normal project costs. ${ }^{53}$

It is not by any means established, as a matter of public policy, that the Government is liable for the reimbursement of all costs incurred by families and businesses which are dislocated by the acquisition of property for public purposes. In urban

"Panuch, op. cit. supra note 40, at 37 .

${ }^{50} \mathrm{lbid}$.

${ }^{61}$ See note 26 supra.

"2 For a description of one group of property owners' complaints with respect to acquisition appraisal techniques, see 106 Conc. REc. 13529 (daily ed. June 27, 1960).

${ }^{3}$ Statement of David M. Walker, Commissinner, Urban Renewal Adninistration, in Hearings Before a Subcommittee of the Senate Committee on Banking and Currency on Housing Legislation of 1960, 86th Cong., 2d Sess. 125, 986, 988,989 (2960). 
renewal, the practice of reimbursement has been carried further than in almost any other field of public acquisition, ${ }^{54}$ possibly because the public purpose behind slum clearance rests on a national responsibility, assumed by statute, to improve living conditions. Nevertheless, the lengths to which the Government should go in shouldering the expenses of displacees is still a question on which responsible policymakers can and do differ. And the policies that may be adopted in urban renewal cannot be isolated from related policies in the highway program or in other forms of public development work.

There is one area, however, in which the rules of urban renewal could be strengthened in order to eliminate a possible source of inequity and hardship. It is in the timing of eligibility for relocation payments. Under existing interpretations of the law, families, businesses, and individuals are not eligible for relocation payments unless they move after the property is acquired in an urban renewal project. This excludes those who move soon after the announcement of a project, or during the lengthy planning period. It is not known how many displacees move under stress before their property is acquired, but relocation experts feel the number is substantial. There are serious administrative difficulties involved in any solution of this situation, but a solution is, nevertheless, being sought, at this writing, by the URA.

\section{Special Problems}

It is widely recognized that urban renewal generally, and slum clearance particularly, have an impact on the nonwhite minorities in our cities far beyond their numerical proportion of the population. Nonwhites are, typically, afforded less opportunity in the employment market and in the housing market, and hence very often make up the predominant group living in the slum and blighted areas that are to be renewed. Of 65,800 families relocated from urban renewal projects up to Iune 30, 1959, fully seventy-two per cent were nonwhite. ${ }^{55}$ This has serious implications for the urban renewal program, because practically all of the problems faced by displaced families are intensified for families which belong to one of the nonwhite minorities.

Nonwhite families in the relocation load tend to have lower incomes than the white families (fifty-seven per cent of the nonwhites were apparently eligible for public housing, compared with thirty-eight per cent of the whites ${ }^{58}$ ). In addition to having lower incomes, they are often required to compete for rehousing space in a relatively restricted market. Historically, the gross supply of housing available to nonwhites has been proportionately less than the supply available to whites. Even

st A notable exception is found in the operations of some special purpose authorities. The Port of New York Authority, for instance, has made payments totaling up to $\$ 560$ per family for bonuses, finders' fees, moving expenses, and decorating costs. Speceh by Robert S. Curtiss, Director of Real Estate, Port of Ncw York Authority, at the Annual Meeting of the Highway Research Board, Washington, D.C., Jan. 8, 1958.

${ }^{6}$ Urban Renewal Administration statistics (unpublished).

${ }^{s}$ Ibid. 
where sufficient housing has been opened up for nonwhites to balance their proportionate share of the population, this housing is usually located in older, congested neighborhoods. Hence the problem is not mercly one of finding access to existing housing, but also one of finding sites where new housing can be built to add to the supply available to nozwhites. The Thompson report on section 221 operations notes that "comments from widely separated sections of the country emphasize that this problem exists even in areas where community customs and patterns supposedly recognize no racial restrictions or where law prohibits them." ${ }^{17}$ As a result of all these factors, the displaced nonwhite is likely to find that he is competing for relocation housing with a smaller income than the white displacee, while supply and demand factors increase the cost of standard housing that is available to him. As the Commission on Race and Housing reported in 1958: "Census statistics indicatethat at every level of rent or market value, non-white renters and home owners obtain fewer standard quality dwellings and frequently less space than do whites paying the same amounts." ${ }^{\text {s }}$

There is still another element that militates against the dislocated nonwhite; his. relatively poor credit standing in the community may make it more difficult for him to purchase new or existing housing on the best terms available to buyers generally. This problem arises from two factors: the unfamiliarity of many nonwhites with the operation of the housing market, and the unfamiliarity of many credit sources with the nonwhite buyer or borrower. A committee of the national Mortgage Bankers Association made a careful, objective analysis of this problem in $1955^{59}$ and the Thompson report noted that it was still a factor in $19599^{\circ 0}$

It is obvious that the relocation of nonwhite families is liable to be considerably more difficult than the relocation of whites. There is no simple solution for the local public agency faced with this problem, but there is one positive value that arises from the nature of the relocation operation and the requirements of federal law and regulations. In urban renewal, the question of nonwhite housing resources. must be brought into the open-and faced-in a way that is not normally required in any other field of activity. Certainly, if a solution is to be found, the first step is to strip away the emotional biases on both sides of the race question and identify the facts of the problem. In this way, urban renewal can contribute to the larger question of housing opportunities generally.

The relocation process can make other contributions as well. Careful relocation practices can contribute to the creation of stable, integrated ncighborhoods, where a community is ready to accept this solution. ${ }^{61}$ Through section 221, urban renewal

${ }^{27}$ Tilomspon, op. cit. stipra note 42 , at 19.

${ }^{83}$ Comms's on Race and Housing, Where Shalz We live 36 (1958).

"Mortcage Bankers Ass'n of America, Report of the Consutree on Financing Minority Housing (r95s).

Co Thospsos, op. cit. supra note 42, at 29.

12 This approach is especially applicable to middle-income, nonwhite farmilies. Such citics as Columbus, Ohio, New Haven, Conn., Providence, R.I., York, P2., and Washington, D.C., among others, have reported experiences of this sort. 
can bring about the creation of new housing resources for nonwhites. The Thompson report found that: ${ }^{62}$

In many communities Section 221 has made a significant contribution to the rehousing of displaced and other minority families. It has opened up new areas to minority occupancy and has made mortgage financing available to minority families who would otherwise not have been able to secure it.

Since October 1959, the FHA has required all section 221 housing units to be offered to displacees on an open occupancy basis, eliminating the racial "quotas" that were possible under earlier procedures. ${ }^{03}$ In several states, moreover, state law requires that new housing built in urban renewal areas be marketed on an open occupancy basis. ${ }^{\circ 4}$ Where redevelopment projects are designed for lower-cost housing, this sort of statute can be an important factor in expanding the supply of housing available to nonwhites.

"Finally, those families who are unfamiliar with the elementary aspects of real estate operations-and are, therefore, subject to exploitation by sharp practitionerscan obtain expert advice and counseling through the urban renewal process. Outstanding pioneer work has been done in this field by several local renewal agencies ${ }^{\circ 5}$ and such private organizations as the Fight Blight Fund in Baltimore, and BlockBlight, Inc., in Wilmington, Delaware. Services such as these are eligible as normal costs of an urban renewal project; and the transformation of an uneducated, vulnerable tenement dweller into a self-respecting and self-sufficient home owner can be one of the most dramatic and rewarding accomplishments of urban renewal.

Other groups which are faced with special problems as a result of relocation are elderly people and large families. The problem of housing large families has been mentioned in connection with the shortage of large units in public housing projects. Large family units are also more difficult to find in the private market, particularly if there is a modern housing code imposing stringent requirements with respect to occupancy limits. The slum, on the other hand, with its disregard of overcrowding standards and other middle-class amenities, has traditionally provided a resource of housing units for large families of limited income. If relocation is to be successful, a local public agency must tackle this problem with imagination and ingenuity. As mentioned previously, the best solution seems to lie in the direction of the rehabilitation and conservation of older existing homes-which were built in a time when construction costs per cubic foot of housing space were much lower.

-2 Tizompson, op. cit. supra note 42 , at 19.

os 6 FHA Manual Bk. I, \$ 1, Processing Appendix (1959).

of As of October 1958, state antidiscrimination housing laws specifically applied to housing in urban renewal areas in Massachusetts, Minnesota, New Jersey, New York, Pennsylvania, Washington, and Wisconsin. Ordinances or resolutions on the same subject (not limited to particular projects) have been adopted in Cleveland, Ohio, New York City, St. Paul, Minn., and Los Angeles, Sacramento, and San Francisco, Cal. Sec Housing and Home Finance Agency, Raciaz. Relations Service and thie Orfice of the General Counsel, Nondiscrimination Statutes, Ordinances, and Resolutions Relating to Prblic and Private Housing and Urban Renewal Operations (1958).

${ }^{\circ B}$ Such as the agencies in Rochester, N.Y., St. Paul, Minn., Florence, Ala., Little Rock, Ark., Ner Haven, Conn., and Washington, D.C., among others. 
The special problems that relocation creates for elderly persons arise largely from the limited incomes and abilities of the elderly persons themselves. It is generally known that the population as a whole includes an increasing proportion of the aged and aging, and a substantial proportion of these are likely to be ill or handicapped. In the I950 Census, it was found that of the dwelling units occupied by families headed by persons sixty-five or older, thirty per cent were either dilapidated or lacked plumbing facilities, or both, compared with twenty-four per cent for younger families. ${ }^{68}$ The needs of elderly people for special types of housing arrangements are now the subject of a growing professional literature, and there is no space to discuss that aspect here. It must be said, however, that the special needs of the elderly, frequently combined with a lack of earning power, create problems that may become critical when relocation is neecssary. Elderly home owners who bave purchased their homes by thrift and hard work over the years may find that they are too old to obtain new mortgage terms within their limited means, and thus cannot replace the dearly-bought home that is being taken from them. This situation can be considerably more serious in cases where the home also supplies the sole source of income, from tenants or roomers. The mere matter of care and protection may also be a problem, especially with elderly women who have been living alone and are separated by relocation from the friends and neighbors who have looked after them.

In general, these factors make the relocation of elderly persons a delicate task, requiring more attention than the normal relocation operation. There are promising efforts under way to supply special housing resources for elderly persons through public housing, special FHA mortgage insurance terms for the elderly, and the Housing for the Elderly loan program initiated by the Housing Act of $1959^{\text {oT }}$

These efforts, and the relocation techniques that are being developed by local urban renewal agencies, will have more effective application if a community recognizes the problem of housing its elderly population as an important element of its general future development plans. This approach has been strongly recommended by the National Federation of Settlement Houses and Neighborhood Councils, ${ }^{68}$ and should be given careful consideration by those responsible for official community objectives. From the more limited point of view of urban renewal, it has been pointed out that Title I of the Housing Act of 1949, as amended, requires a relocation plan and a demonstration of adequate rehousing resources for families, but not for individuals. ${ }^{69}$ To the extent that elderly persons are classified in the latter category, they are afforded less legal protection than is normally provided for families. In

"Comp. on Housing, Witte House Conference on Aging, Background Paper on Housino (1960).

"7 so Stat. 891 (1937), 70 Stat. 1103 (1956), 73 Stat. 680 (1959), 42 U.S.C.A. $\$ 5$ 1401, 1402, 1410 (Supp. 1959); 70 Stat. Iogr, I2 U.S.C. S5 1710, 1713 (1958); 73 Stat. 665, 12 U.S.C.A. \$ 17156 (Supp. 2959).

"Nat'l Federation of Settrements and Neigiborhood Centers, Amendments to Existikc Resolutions Adopted at the Annual Meetno (Boston 1960).

"Sce note 222 supra. 
fairness, however, it should be said that local public agencies generally treat individuals with the same care as families in those cases where there is a need for relocation services.

\section{IV}

\section{Business ReLocatron}

The foregoing paragraphs have dealt with the relocation of families and individuals from urban renewal project areas, intentionally omitting any extensive treatment of the problems faced by dislocated business firms. This is a different subject, with problems and opportunities of its own.

In the first ten years of urban renewal, the dislocation of business has been substantial, but hardly massive. By the end of June 1959 , a total of $11,25 I$ nonresidential establishments had been relocated (including churches, schools, and other institutions) and the annual rate of displacement was about 3,700 per year. ${ }^{70}$ In the main, these establishments have included businesses and institutions which happened to find themselves in the midst of blighted residential areas. Their relocation was incidental to the objectives of urban renewal, in a sense that the relocation of families was not. There has been a growing trend, however, to provide governmental powers for the renewal of all types of urban obsolescence, including nonresidential areas as well as residential. Prior to 1959, several dozen urban renewal projects were undertaken in "skid row" areas, where the elimination of slum housing was secondary to the removal of nonresidential blight. The Housing Act of $x 959$ expanded .this movement to major proportions by providing that twenty per cent of the federal urban renewal grants may be spent in purely nonresidential areas, regardless of whether new housing is to be created after the blight has been cleared away. ${ }^{71}$ Localities are now able to initiate projects in which the relocation load will be almost totally composed of commercial and industrial establishments.

In the relocation of businesses, as in the relocation of families and individuals, 2 problem is created simply by the cost of moving to a new location. As with families, the federal law provides for relocation payments to cover moving expenses and unavoidable losses of personal property, and the maximum payment appears to be adequate to cover these items in a majority of cases. The maximum in the case of nonresidential establishments is $\$ 3,000$, and the average payment made through the $1958-59$ fiscal year was $\$ 1,041.55 .^{72}$ There is increasing evidence, however, that the average figure conceals a substantial minority of cases where the existing limit on relocation payments is grossly inadequate. Instances have been reported by urban renewal officials where the actual cost of relocating certain types of business firms (such as printing plants, which have large amounts of heavy equipment, or ware-

\footnotetext{
${ }^{70}$ Urban Renewal Administration statistics (unpublished).

7173 Stat. 675, 42 U.S.C.A. I 1460 (Supp. 1959).

12 Urban Renewal Administration statistics (unpublished). Of the total amount paid to businesses, $40 \%$ was accounted for by losses of property and $60 \%$ by moving costs.
} 
houses, where the contents must be moved) may be as high as ten or more times the amount of the maximum federal payment.

The HHFA has recognized that the existing statutory limits on relocation payments may create hardships and has recommended legislation, as mentioned above, ${ }^{73}$ to increase those limits substantially in communities where the cost of the payments can be shared by the local government in the same manner as other project costs. Similar proposals have heretofore received the endorsement of the Senate and of the Banking and Currency Committee of the House of Representatives ${ }^{73}$-indicating that some liberalization of the relocation payment language will be enacted in the near future. As in the case of families, however, the legislation cited would not affect the types of expenses for which payments may be made. The most important type of expense which is not covered by existing law is the loss of business or good will suffered by a firm as a result of relocation. There is not yet any general agreement that the Government should be responsible for this loss when property is acquired by public action, whether it be for urban renewal or some other purpose.

While the cost of moving to a new location affects almost all dislocated businesses, there is a far more serious problem confronting some-the question of survival. From the figures compiled by the URA and from other studies, ${ }^{75}$ it appears that perhaps twenty per cent of the businesses occupying acquired property may fail to relocate successfully and go out of existence. The studies indicate that these are most likely to be marginal, small, retail establishments, or firms with special licensing or zoning requirements.

It is not surprising that the smallest firms are often the hardest hit by relocation. ${ }^{26}$ This is probably because the small business has less capital with which to secure and prepare a new place of business (particularly if the displacee was a tenant), a lower credit rating, and less ability to pay the higher rents required for space outside of the slum. The small proprietary business is also more likely to be owned and operated by a businessman who is elderly, and unable to adapt to a new location. If a business not only is small, but also is engaged in retailing, it is especially vulnerable to dislocation. Many types of retailing require little specialized knowledge or skill, and success tends to depend on the customers who find the store's location convenient to their normal activities. The corner grocer or druggist, who relies almost entirely on a neighborhood clientele, may find that slum clearance disperses his customers over other parts of the city. In any case, he finds it a risky and discouraging business

${ }^{72}$ See note 53 supro.

"See S. $3670,5403,86$ th Cong., 2 d Sess., passed by the Senate on July 16, 1960; and H.R. 12603, 5801,86 th Cong., $2 d$ Sess., reported by the House Banking and Currency Committee on June 20, 1960.

${ }^{73}$ Greater Boston Economic Study Comm., Business Relocation Caused by the Boston Centrat Artery table 4 (Boston, 1960); Baltimore Uzbas Resewal axd Housing Agency, The Displacement op Sacall Businesses for a Sluai Clearance Area 2 (1959).

${ }^{16}$ Grester Boston Economic Study Consk., op. cit. supra note 75, table $5 A$. It was found here that $100 \%$ of the firms with more than 100 employees survived, compared with $90 \%$ of those with 50 to 100 employees, and $73 \%$ of those with 2 to 5 employees. 
to create a new clientele in an unfamiliar site..$^{77}$ If the small retail business has also been operating under a license, such as a liquor-dispensing license, or with a zoning exception or nonconforming use, he may find an additional obstacle in the way of a successful move.

In addition to the problems faced by business firms themselves, there is the possibility of loss to the economic position of the city as a whole when a nonresidential area is acquired and cleared. The stronger and more prosperous firms have greater ability to move and may leave the city, taking with them their tax-paying ability and employment. ${ }^{\text {r8 }}$ This is more serious in a case where the cleared site is to be occupied by a public use, such as a highway, than in a case where private enterprise is expected to redevelop and occupy the land. In determining whether the new uses will represent a net economic gain, however, the loss of the previous occupants should be considered.

While the techniques of relocating business and other nonresidential establishments from urban renewal areas are still relatively new, several directions can be suggested in which solutions may lie. It has been pointed out earlier that the federal statute requires a relocation plan and, in effect, a relocation service for dislocated families, but not for dislocated individuals or businesses. Nevertheless, if relocation services are provided specifically for businesses, they are eligible as normal costs of an urban renewal project, and several cities, such as New Haven and Baltimore, have been providing expert assistance of this type. The problems faced by dislocated businesses are so complex-particularly for small businesses which are not normally accustomed to utilizing expert real estate and managerial advice-that the availability of expert advice appears to be essential to achieve successful relocation in any area where there are substantial numbers of business concerns. ${ }^{79}$

The Small Business Administration has for some time been working in cooperation with the URA in providing for assistance to small business concerns affected by urban renewal projects. SBA has issued instructions to its Regional Directors to appoint representatives for the purpose of maintaining liaison with local, state, and federal authorities connected with urban renewal. It is a function of these representatives to meet and counsel with the owners and managers of individual small

${ }^{77}$ Grenter Boston Economic Study Comm., op. cif. supra note 75, table 4. This study found that approximately $85 \%$ of the firms engaged in manufacturing, wholesaling, and service activities survived, compared to only $56 \%$ in retailing. The latter figure is probably high, since the study omitted some 300 businesses which had less than two employees. Among the retailers who survived, total $\mathrm{cm}$ ployment declined in the year after relocation, indicating that it was difficult to carry on at some of the new locations.

${ }^{78}$ Greater Boston Economic Study Conims, op. cit. supra note 75, tables 10, 13, Summary of Findings. The relocation caused by the Boston Central Artery cost the city 1,348 of the 7,160 jobs formerly provided by the displaced firms; $40 \%$ of this loss was attributable to migration. Although only two of the 455 displaced firms moved outside the metropolitan area, 35 moved to the suburbs beyond the city limits.

70 Greater Boston Econonic Study Comms, op. cit. supra nate 75, table 15D. Among the businesses relocated by the Boston Central Artery, where no such services were available, $52 \%$ of the relocated businessmen who were interviewed expressed a desire for help in understanding municipal regulations, and $58 \%$ in analyzing building, renting, and tax costs. 
business concerns who may require technical and financial aid, and to inform them of the types of assistance available from SBA. These are: (I) technical and management advice; (2) special consideration in obtaining small business loans; and (3) occupational and vocational retraining for proprietors who fail to relocate, and their employees. ${ }^{80}$

There are other important ways in which the problems of dislocated businesses can be relieved. In New Haven, Connecticut, Providence, Rhode Island, and Washington, D.C.-to name only three-arrangements have been made for businesses that formerly occupied a project site to act as redevelopers, either separately or in the form of syndicates. The latter arrangement is especially adaptable for small firms, because project land is normally marketed in parcels too large for a small establishment to finance unaided. In New Haven, the city has taken the further step of providing a temporary site, on which a syndicate of small businesses can operate until its cleared slum site is ready for occupancy. ${ }^{81}$ Several bills have been proposed in Congress in recent years which would require a local urban renewal agency to give a priority to dislocated businesses when disposing of cleared sites. HHFA has endorsed this objective, but opposed the adoption of a law to require it in every case, on grounds that it might interfere with a community's opportunity to plan the reuses of project land in terms of what is best for the city as a whole, and that land prices might suffer if such additional restrictions should discourage potential redevelopers who were not formerly located in the area. ${ }^{82}$

Other ways which have been suggested to ease the burden of relocated businesses -ways which would require the enactment of substantial new legislation-include the provision of liquidation payments for businessmen who fail to relocate (this could also take the form of a relocation payment for the loss of good will, limited to those who go out of business) and the creation of a federal guarantee of small business leases-much like an FHA guarantee of a home mortgage. The latter idea has been suggested by Planner Victor Gruen as a solution for the situation of small retailers who are displaced from an urban renewal site, only to see new retail stores go up in the redeveloped area, leased to outlets of large chain concerns. The reason that redevelopers turn to the chain stores, according to Gruen, is the high credit standing that is necessary to back up redevelopment financing. If the federal government provided a credit base for small businessmen, he reasons, they, too, could afford leases in new shopping centers and other commercial buildings. 88

\footnotetext{
${ }^{80}$ For details, see letter from Philip McCallum, Administrator, Small Business Administration, to Albert Rains, Chairman, Subcommittee on Housing, House Committee on Banking and Currency, June 15, 1960; Small Business Administration, SBA Services for Commuunity Economic Development (1960).

12 Relocation News, 16 J. Housing 239 (1959).

-2 Statement of David M. Walker, Commissioner, Urban Renewal Administration, in Hearings Bejore a Subcommittee of the House Committee on Banking and Currency on General Housing Legislation, 86th Cong., 2d Sess. 90 (1960).

${ }^{83}$ Gruen, Relocating Small Businesses in Large Shopping Centers: Why Isn't It Being Done?, 6 J. Housisis 237 (1959).
} 
In conclusion, it should be emphasized that relocation is not necessarily a bad experience for business concerns. It provides an opportunity in disguise for some, by forcing them to give up timeworn and obsolete premises and methods. A good example is cited in the study of relocation experience connected with the acquisition of property for the Boston Central Artery. Thirty-six of the dislocated firms were meat-packing plants, and although six of them went out of business, the others found sites in a new area outside the central business district. The new area was apparently better suited for their type of operation, because three years after relocation, the remaining plants had doubled in total employment. All told, forty-seven per cent of the businessmen relocated from the path of the Boston Central Artery said afterward that they preferred their new location, compared with twenty-six per cent who preferred the old, and twenty-seven per cent who saw no difference. Thirty-four per cent reported an increase in business volume after relocation, and half of these gave the new location as the reason..$^{84}$

$\mathbf{V}$

\section{The Human Factor}

$U_{p}$ to this point, we have been discussing relocation primarily from the point of view of the relocator-the one who is concerned with getting the job done. Again and again, however, it has been clear that success depends in large measure on the attitude of the relocatee. We have seen that a large segment of low-income families in the relocation load will not accept public housing and that new housing built under section $22 \mathrm{r}$ will not be bought by relocatees unless it meets their needs and desires with respect to location, price, and design. The number of families who are relocated in standard housing of any kind depends to a degree on their willingness to accept the assistance offered by the local public body and to adjust to new living standards and new neighborhoods. Similarly, if dislocated businessmen are not willing to seek new opportunities and new methods, they may become casualties of the relocation process. The success of a relocation program for nonwhites, depends partly on the maturity and responsibility with which the situation is handled by the nonwhites themselves. In short, it behooves us to look at relocation for a moment through the eyes of the people involved. What are their attitudes toward relocation, and how will these attitudes affect the success of the urban renewal undertaking?

In the first place, a clear distinction should be (but often is not) made between the attitude of a relocatee at the time he is forced to move and his attitude some months or years later, when he may have realized the advantages of a new location and a decent, safe, and sanitary home. The short-term reaction is naturally negative. No one likes to be forced to leave his accustomed home and neighborhood, where he has made the difficult adjustment to his lot, and where more often than not he

"Greater Boston Economic Study Comm., op. cit. supta note 75, notes for table 5, tables ISA, 15C. 
has been able to associate with others who have the same customs and institutions, the same problems and tastes, and even, in many areas settled by foreign-born and firstgeneration Americans, the same language. In addition to the relocatee's normal reluctance to leave familiar surroundings, there are those who resist the change because of an innate suspicion of officialdom, or because they do not know that they can afford better housing in a better neighborhood, or because of fear that they will not be able to conform to the living standards of such a neighborhood. There are others who prefer the slum, with its anonymity and its opportunities for selfsufficiency, independence, and mobility. ${ }^{85}$ Still others have achieved a respectable, middle-class life in the slums because of the opportunities for economy in family budgeting. They resent the label of "slum," and the implication that they need public assistance. Recent in-migrants from rural areas, on the other hand, are apt to prefer their rural habits of life and to resist suggestions that they should learn urban ways. ${ }^{80}$

While these attitudes explain the negative initial reaction of slum residents to the idea of relocation, they may also have a strong bearing on the long-term possibilities of eliminating slums and blight. Will the people who lived in the slum merely create new slums wherever they move? Or is it possible to "rehabilitate the people" by relocating them in decent, safe, and sanitary housing? Undoubtedly, the answer is "yes" and "no" to both questions; some pcople will be transformed by the process, and others will not. A revealing analysis of the residents of a redevelopment area was made in Indianapolis, Indiana, in 1955. The residents were classified according to their reasons for living in the area, and the result showed that some are permanently confined to the slum by necessity (social outcasts, the indolent, the "adjusted poor"), while others are there only by temporary necessity (the "respectable poor," the trapped). Some, on the other hand, are permanent slum residents as a matter of choice (fugitives, those who are addicted to antisocial habits) while still others choose to live there temporarily because of the savings that are possible (young families, beginning entrepreneurs) ${ }^{87}$

This analysis suggests strongly that anyone who is responsible for a relocation program should first understand the functions that have been performed by the slum that is to be wiped out. It is well known that the slum harbors antisocial elements who will create problems whether the physical structures are cleared or not. It is not so often recognized that the slum represents a way of life that is quite different from that of middle-class neighborhoods. Professor Herbert Gans, reporting on ten months that he spent in a Boston slum-clearance area, points out some of the differences: the lack of emphasis in the slum on privacy and on status symbols

\footnotetext{
s This is exemplified by the prevalence of weekly rents in slum areas, as opposed to monthly rents and contractual leases in "better" neighborhoods.

"Considerable light has been shed on the attitudes by several sourees. See Gans, supra nute $\mathrm{I}$; Phil.adelphila Housisg Ass'v, op. cit supra note 30; Citrine \& Moore, Redevelopment and the Social Worker, 14 J. Housine 330 (1957).

it Community Surveys, Inc., Redevelopanent: Some Human Gains and Losses 48 (1956). This study should be required reading for urban renewal administrators generally, and for relocation specialists spccifically.
} 
connected with exterior appearances; the social grouping around kinship and ethnic connections, instead of the self-sufficient single-family unit of the middle-class area. ${ }^{88}$ The midde-class citizen (which includes most planners and urban renewal administrators) may feel that residents of the slum would prefer to be able to follow middle-class ways, but this may be far from the truth. John Seeley, one of the authors of the Indianapolis study, makes this point in an account of life in the slum: $:^{80}$

I would have to say, for what it is worth, that no society I have lived in before or since, seemed to me to present to so many of its members so many possibilities and actualities of fulfillment of a number at least of hasic human demands: for an outlet for aggressiveness, for adventure, for a sense of effectiveness, for deep feelings of belonging without undue sacrifice of uniqueness or identity, for sex satisfaction, for strong if not fierce loyalties, for a sense of independence from the pervasive, omnicompetent, omniscient authority-ingeneral, which at that time still overwhelmed the middle-class child to a greater degree than it now does. These things had their prices, of course-not all values can be simultaneously maximized. But few of the inhabitants whom I reciprocally took 'slumming' into middle-class life understood it, or, where they did, were at all envious of it. And, be it asserted, this was not a matter of 'ignorance' or incapacity to 'appreciate finer things.' It was merely an inability to see one moderately coherent and sense-making satisfactionsystem which they didn't know, as preferable to the quite coherent and sense-making satisfaction-system they did know.

Finally, the slum shelters a major portion of the social problems of the city, ranging from juvenile delinquency, alcoholism, and narcotic-addiction to imbecility, insanity, promiscuity, separation, desertion, and divorce. Of the $r, 400$ families who were the last to be relocated from the District of Columbia Area $C$ redevelopment project, thirty per cent were-broken families with children; twenty-five per cent reported illness that affected earnings; forty-eight per cent had suffered unemployment within the last two years; and thirty-eight per cent had been on the public assistance rolls at one time or another. ${ }^{90}$ Relocation has a twin-edged effect on such families. On one hand, the stress of being uprooted may complete the disintegration of a family that has been precariously close to breaking up, or aggravate any other problem that already troubled a family. On the plus side, however, the process of relocation can bring to light problems that might otherwise have been suffered in silence by families who are ignorant of the forms of assistance available to them. Indeed, a roo per cent relocation effort could, ideally, identify almost all of the social and educational problems in a specific area and provide the opportunity for bringing expert attention to bear on them.

Can the expert attention be provided? Are the social resources of the community tooled up for the task? This does not now appear to be the case in many cities. The problem families who are displaced from slum-clearance areas have specific needs for: (I) information on what social services are available to them; (2) a central

${ }^{88}$ Gans, supra note 1, at $15,17-18$.

${ }^{80}$ Seeley, The Slum: Its Nattre, Use, and Users, 25 J. Axr. Inst. of Planners 10 (1959).

80 These statistics, supplied by the Redevelopment Land Agency, District of Columbia, were developed as part of a Demonstration Project being conducted in the District of Columbia with the assistance of a grant from the Urban Renewal Administration. 
referral point, where they can obtain access to all types of social services; (3) assistance with groupings of problems which are not separable, but interlocking, both within families and between families; (4) the immediate availability of the appropriate social services, without long waiting lists or qualification periods; (5) education in home management, nutrition, health and hygiene, maternity and child care; and (6) advice and guidance in home financing, budgeting, and contracting. These needs are accentuated in a relocation situation, because at that time, the normal sources of help in the area are drying up. The citizen leaders of the neighborhood are likely to be the best able to move, and, therefore, the first to go; settlement houses and churches are being relocated themselves, usually ahead of the hard core of problem familics; there is a vague, but very real, lack of interest shown by the community generally in a neighborhood that is disappearing-that has no future.

This puts the task on the doorstep of community-wide social agencies-both public and private. Normally, such agencies do not have a centralized referral system, so that one visit will lead a client quickly to the proper source of help. Also, each social agency may deal with only one aspect of family life; and so there is little experience or motivation for coping with combinations of interlocking problems. ${ }^{91}$ Finally, the social agencies are not as a rule equipped to solve family problems on an area, or saturation, basis. The normal sources of the case load are complaints, referrals, and walk-ins.

\section{VI}

\section{IMPLICATIONS}

\section{A. For Planning}

As the urban renewal movement has prospered and grown, gathering support and momentum from a broad spectrum of interests, including downtown businessmen, civic leaders, and even suburban taxpayers, the pendulum has swung away from the housing orientation of the 1949 Act and toward a concept of "city rebuilding," or of the renewal of obsolete land uses generally. Among the forces that create an urban renewal project, economic motivations have become more and more important: the need for additional tax revenues to relieve the crisis of municipal finance; the desire to attract middle and upper-class families back to the city; the incentive of preserving old real estate investments and creating opportunities for new ones; and the urge, sometimes born in desperation, to create a tour de force of open space and architecture that will spark a "revival" of the central city. In relation to these motivating factors, relocation becomes simply a tool of land clearance, subordinated to the primary objective of redevelopment.

At the same time, however, there has been a growing awareness of the social problems that are uncovered by relocation and of the further complications that relocation sometimes adds to such problems. In most cases, the process of slum clearance and redevelopment has but a negative connection with low-income housing

" CF. Pimladelphia Housing Ass's, op. cit. supra note 30, at 31-32. 
the elimination of unsafe and unsanitary dwelling units. The only way in which slum clearance has directly assisted in the improvement of housing conditions for slum dwellers has been through the relocation process; and here is where the attention of those whose motivation is social, rather than economic, is beginning to focus. While the economic motivation is no less worthwhile, it becomes important to recognize that the two basic motives-economic and social-may be present in any given project, and they may come into conflict with each other.

On another level, there is a potential conflict between (I) the objectives of planners who are educated to lead the community toward a middle-class ideal, and ( 2 ) the wishes of the residents of slum and blighted areas, who may want to continue their traditional customs. The potential contrast between these standards has been described above. In practice, this may become a problem not only in carrying out a relocation plan, but also in the selection of project areas in the first instance. The planner who determines the eligibility of an area for redevelopment must be extremely cautious not to confuse the condition of structures and facilities with the habits of slum dwellers. Housing sometimes appears obsolete only so long as it is inhabited by members of a lower social class, as amply demonstrated in the Georgetown and Capitol Hill sections of Washington, on Baltimore's Tyson Strect, and in sections of Greenwich Village and Chelsea in New York City.

These potential conflicts are sure to be recognized more widely as the scope of the urban renewal program grows and as the cities' renewal activities progress beyond the obvious opportunity areas into the "grey belt," where objectives are not so easily identified. Increasing numbers of urban renewal planners and administrators are becoming concerned about the question of objectives and are seeking means of identifying goals that can be understood and endorsed by the community as a whole. ${ }^{32}$ From the point of view of relocation, this requires a search for planning solutions that will reconcile economic motives with social concerns and provide the relocated slum dweller with new facilities for the satisfaction of his needs and desires. $U_{p}$ to now, our preparation for this job has probably been inadequate, and very few communities have thought of relocation in qualitative, as well as quantitative, terms. But the slum, as we have seen, performs functions that are very real-not the least of them being the provision of cheap housing for those who need it and are unable, or unwilling, to resort to public housing in its present form. Many of these people can take very good care of themselves once they are shown how, as demonstrated by the experience of the Fight Blight Fund in Baltimore. ${ }^{93}$ Others need help with

"2 "The End Product of Urban Renewal" was the theme, and the search for objectives the topic of greatest interest, at the annual Working Conference of the National Association of Housing and Redevelopment Oficials, held at the Institute of Government, University of North Carolina, Chapd Hill, N. C., in March 1960 .

${ }^{9}$ Slum home owners are referred to the Fight Blight Fund if they have no appareat financial resources with which to make the housing improvements required by code cnforcement. Experience with more than 300 such cases has shown that more than $80 \%$ actually needed legal and financial advice, rather than money. Sce Martix Milispaugh \& Gurney Breckenfeld, The Huasan Side of Urban Renewal. ch. $x \cdot(2960)$. 
serious social or emotional problems before they can enjoy a satisfactory life away from the palliative conditions that are peculiar to the slum. These factors suggest that a community will have little long-term success with the busincss of eliminating slums and blight unless relocation is given the status of a positive program, based on the specific needs and desires of the relocatees, and geared to the rehabilitation of problem families and others who need help.

The first step in creating such a program would be identification of the size of the relocation load that will be created by urban renewal and similar activities, together with the predominant characteristics of the people involved. Thus identified, the total need can be measured against the community's potential relocation resources, and a program developed to meet deficiencies in the community's current and future ability to supply both relocation housing and the necessary rehabilitative services for human problems. A major part of this analysis can be assisted with federal funds under the provision in the Housing Act of 1959 for grants to assist communities in the preparation of total community renewal programs. ${ }^{94}$ Relocation is an essential element of such a program, and relocation planning should play an essential part in the selection and scheduling of specific projects.

The next step is the detailed planning of those projects, and here a thorough understanding of the people who live in the slum becomes increasingly important. Almost every one of them will dislike the prospect of being relocated, but it is now clear that the process can be an important opportunity for many. ${ }^{95}$ In project planning, it will be important to distinguish between those who will be helped by relocation and those who may be hurt, and to provide for each category to be treated accordingly. This requires a face-to-face acquaintance with the residents of the project area, and a thorough knowledge of their problems, their resources, and their aspirations. It makes very little difference, apparently, whether the project involves clearance, conservation, or rehabilitation. In any of the three, the solution of a family's housing problem will often require the prior solution of a serious social, financial, or legal problem.

\section{B. For Operations}

The need to plan for the total impact of relocation has been mentioned above. Obviously, such planning cannot be restricted to the relocation load that will result from urban renewal, because urban renewal relocatees will be competing in the housing market with those who are relocated by other public and private development programs. Similarly, it appears logical for the organization of a relocation program to focus responsibility for all relocation operations in the community at one central point. This may or may not mean a central relocation agency, as recom-

"See note $2 x$ supra.

${ }^{\circ 5}$ See Thompson, op. cit. supra note 42; Citrine \& Moore, stipra note 86. Thompson indicates the advantages of relocation to minority families who never before had access to mortgage financing or to expert assistance in finding a home. Citrine and Morse, in their article on Portland, Mainc, indicate that relocation can provide the younger geseration with a route of escape-from a life situation that is dominated by an older generation with different standards and customs. 
mended by NAHRO in $1959 . .^{96}$ Nevertheless, the advantages of a central relocation agency (it provides a trained staff in continuous operation, maintains a single listing service of available rchousing units, eliminates competition for those units, and tends to prevent the subordination of relocation to redevelopment-putting the emphasis on thoroughness rather than speed) appear to outweigh the disadvantages (it creates difficulties in coordinating relocation with site acquisition, management, and demolition). In addition to a central relocation responsibility, it can be recommended that there be a central record-keeping system, to record experience and results; that citizen advisory committees should be set up on the community level and also the neighborhood level; and that the relocation staff should establish permanent relationships with courts, social agencics, neighborhood councils, churches, and the press. $^{97}$

The selection of the relocation staff itself is of paramount importance-second only to the matter of housing supply. ${ }^{98}$ In many ways, the characteristics of a good relocation specialist are the same as those required for any form of counseling. But there is more to it than that, because a good relocation specialist must be able to produce treatment as well as diagnosis. One southern city has compiled an excellent relocation record with a team of two: a social worker, who is able to determine what sort of help a displaced family needs, and a politician (formerly the local sheriff), who knows how to get it. A good relocation specialist may come from almost any walk of life; the essential element is the attitude with which he approaches the cases presented to him. ${ }^{92}$

After staff selection (and training), it is essential to establish communication between the staff and the residents of the project area-starting with the beginning of the planning stage or even earlier. The Demonstration Project conducted by the District of Columbia Redevelopment Land Agency has shown the need for a maximum exposure of project area residents to the facts about relocation-well before any moving actually begins. The method adopted in this case was to hold a series of orientation courses for residents, covering (I) the nature of the city's program as a whole, (2) finding a new home, (3) living in a new neighborhood, and (4) community resources and citizenship. In Pittsburgh, the same objective is achieved by holding block meetings for future relocateè, where relocation officials and neighborhood representatives explain what is going to happen and answer questions about the assistance that will be provided. After contact has been established, communications between relocators and relocatees can be maintained by providing a relocation office in the project area, with offce hours on evenings and weekends, and by keeping contact with every family that moves, whether it is moved with the assistance of the relocation staff or not.

'Nat'l Ass'N of Housing aNd Redevelopaient Officials, op. cit. shpra note 24, at 4.

"7 Cf. Meltzer \& Orloff, supra note Ir.

-8 This is the unanimous conclusion of members of the Relocation Branch of the Urban Renewal Administration, who have inspected scores of relocation programs operating under a variety of conditions in all parts of the country.

Ibid. 
Finally, the prevalence of social problems in a project area and the aggravation of those problems by the relocation process indicate the need for close coordination between social work and relocation operations-including, perhaps, the presence of some social work technicians on the relocation staff. The burden of social work will probably have to be handled by the social agencies, however, and a list of the rules that should be followed, in the light of experience with relocation to date, might go as follows:

I. Anticipate and plan for the total relocation load.

2. Establish a central focus of responsibility for all social agency services.

3. Establish a simple, speedy means of referral between agencies, with a staff member in each agency designated to give special priority to relocation cases.

4. Prepare and distribute in urban renewal areas complete information on the social services that are available, and how to obtain them.

5. Provide coordination between agencies, to permit simultaneous treatment of whole families, rather than isolated treatment of separate problems.

6. Provide follow-up services after a family has been relocated in a new neighborhood, to help with adjustment problems.

7. Organize educational and technical advisory services where they are lacking.

\section{VII}

\section{OppoRtunity}

It is hoped that enough has been said in the foregoing pages to indicate why it is possible to view relocation as an opportunity, rather than as an unpleasant duty. For the first time, it is possible to identify the needs and problems of a city's less fortunate families on a concentrated area basis and to diagnose and treat those problems in a systematic fashion. Many of the problems will defy solution-they are as old as the human race-but there is reason to expect that enough can be accomplished, in the form of raised aspirations and improved standards of living, to make a positive relocation program one of the most important and rewarding elements of the community development process.

This does not stop with the solution of social problems or the rescue of problem families. It should also be possible, when such a program is in operation, to provide facilities for education in urban living on a saturation basis-in the areas where in-migrating families make their first home in the city. The importance of this opportunity does not have to be emphasized when it is realized that central cities are experiencing a steady stream of in-migration and every family educated or otherwise assisted out of the slum is immediately replaced by another family with little or no competence for urban living.

Finally, the task of relocation is inextricably involved with even broader community problems, which also arise from population movements. The need for stabilizing racially-changing neighborhoods, the exclusion of nonwhites from suburbia, 
and their growing dominance in the central cities-these are matters that can be laid bare for inspection and constructive action under pressure from the need to relocate thousands of families from the path of urban progress. When the community has been brought face to face with these problems of its own creation, and not until then, a start will be made on the road to finding solutions.

This is not to say that relocation can become a program to settle every frailty that urban man is heir to. But it can provide some magnificent opportunities for service and accomplishment. The "do-gooders," who have social responsibilities as their primary motivation, are also reluctant to stand in the way of progress. The "operators," who want to get the redevelopment job done, are at the same time anxious that no one should be hurt unnecessarily. Both groups should be able to do their work more effectively if the social program (relocation) is distinguished from the economic program (redevelopment) and given equal status in the spectrum of community development activities. This should remove some of the veil of confusion that now hampers the search for community objectives and help a community make the decisions, both economic and social, that are necessary to a successful urban renewal program. 